\title{
Assessment of Oreochromis aureus caught by different fishing techniques at Lake Borollus, Egypt.
}

\author{
Abdou A. Al-Sayes, El-Azab E. El-Bokhty, Tamer El- Bittar and Affiffi Ibrahim
}

Fishing gear lab., National Institute of Oceanography and Fisheries, Alex., Egypt.

\section{ABSTRACT}

Evaluation of Oreochromis aureus caught from Lake Borollus was studied based on the length-frequency of samples collected by different fishing gears. Analysis of the data using (FiSAT) computer program returned the estimate of the von Bertalanffy's growth curve parameters as: $L_{\infty}=18.28 \mathrm{~cm}$ (total length); $k=0.87$ year $^{-1}$ (for Lokaffa), $L_{\infty}=19.32 \mathrm{~cm} ; k=0.41 \operatorname{year}^{-1}$ (for Trammel), $L_{\infty}=17.19 \mathrm{~cm} ; k$ $=0.42$ year $^{-1}$ (for Basket traps) and $L_{\infty}=14.55 \mathrm{~cm}, \mathrm{~K}=0.39$ year $^{-1}$ (for Al-qerba). Very narrow selection range was observed and its upper limit didn't exceed $11.53 \mathrm{~cm}$ in most of the investigated fishing gears except that of trammels which reached 12.11 $\mathrm{cm}$. The total mortality coefficient "Z" was found to be 3.05, 1.83, 1.46, and 1.58 year $^{-1}$ corresponding the fore-mentioned fishing methods respectively. Also, their respective natural mortality coefficient "M" was 1.67, 1.01, 1.06, and 1.06 year $^{-1}$. The estimated exploitation rate "E" was $0.45,0.45,0.28$ and 0.33 respectively. Their relative yield and relative biomass per recruit analysis showed that the stock of $O$. aureus is moderately exploited and more effort could be added to reach the maximum sustainable yield and at the same time larger mesh sizes of fishing nets should be used to increase the mean lengths at first capture and also to conserve the reproducible part of $O$. aureus population.

Keywords:

\section{INTRODUCTION}

Egypt has various inland fishery resources, namely the Nile River including its irrigation canals, six northern coastal lagoons (Mariut, Edku, Borollus,Manzala, Port Fouad and Bardawil). All of these lakes, with the exception of Lake Mariut, are directly connected to the sea (El-Ganainy, 2006).

Borollus Lake is a region of outstanding importance in terms of its contribution in of fish food security. This Lake is considered as one of the important fishing areas in Egypt. The annual fish production of Borollus Lake during 2009 was found to be 53401 tons representing about $47.2 \%$ of the northern Nile Delta lakes. Tilapia species represent major category of the catch (38.81\%), followed by catfish $(21.74 \%)$ and gray mullet (14.44), (GAFRD, 2009).

Tilapia species in Lake Borollus are represented by Oreochromis niloticus, Oreochromis aureus, Sarotherodon galilaeus and Tilapia zillii.

Fishing activity has been proposed as the first major human disturbance to coastal areas (Jackson et al 2001), and evidence of fishing activity going back to ancient times.

Both of the passive and active fishing gears are used in the lake Borollus. Among the passive gears are basket traps, gill nets and trammel nets, while the active gears were are mostly the dragged gears such as Lokaffa and Alqerba (Local names).

The biology of various aspects of Tilapia species have been studied by many authors e.g. Khalifa et al., 2000 ; Abd-Alla and Talaat, 2000; Khallaf et al., 2000; and 
Khallaf, 2002. Fishing gears used in this study were mainly investigated by Al-Sayes, 1976, 2002 \& 2005. While few studies concerning the fishing activities impacts on fish populations were carried by Ishak et al. (1985); El-Bokhty (2006, 2009 \& 2010).

The present study is an attempted to estimate the fishing activities impacts on the dynamic parameters of Oreochromis aureus population in the Lake Borollus using the length frequency data in a predictive analysis. This may help in the sustainable management of Tilapaia spcies in this lake.

\section{MATERIAL AND METHODS}

Fish samples of the commercial catch of Oreochromis aureus were taken by various gears working at Lake Borollus was undertaken during 2002 - 2003.

These gears are traditional ones used for the last 50 years without introducing significant modifications to either their designs or fishing techniques.

Trammel net is the most common one at lake Borollus and used to catch Tilapia and grey mullet. Hanging of three walls of webbing to a single cork or lead line makes the trammel net.

Lokkafa is a sack like net some $8.0 \mathrm{~m}$ long fastened to a wodden frame shaped like an inverted (V): The net is funnel shaped, hanged to the side of the boat while in operation where it is laid down during sailing to drag the bottom of the fishing area.

El-Kerba net is more or less similar to Lokkafa in its fishing technique although smaller in size where a triangle frame having a sharp iron base forming the base of the triangle.

Basket traps used at lake Borollus are of the non return basket type. A typical trap has one hoop horizontally elliptical. To attain good catch these traps are set usually among aquatic vegetations.

The length frequency distributions of $O$. aureus were analyzed using the appropriate routines and subroutines of the "FiSAT" computer program (Gayanilo et al., 1997). An estimate of the asymptotic length $\left(\mathrm{L}_{\infty}\right)$ and the growth coefficient $(\mathrm{K})$ were obtained by the method of Wetherall (1986). The parameters were then used as seed values in ELEFAN I routine (Pauly, 1984 a \&b) for estimating the best combination of $\mathrm{L}_{\infty}$ and $\mathrm{K}$.

The instantaneous rate of total mortality ( $Z$ ) was derived from the length converted catch curve method described by Pauly (1983). The instantaneous rate of natural mortality (M) was computed from the empirical equation of Pauly (1983) considering the mean annual temperature of the lake as $22^{\circ} \mathrm{C}$ (Alsayes et al 2007).

The instantaneous rate of fishing mortality $(\mathrm{F})$ was extracted as $\mathrm{F}=\mathrm{Z}-\mathrm{M}$. The exploitation ratio was calculated as $E=F / Z$. The length at first capture " $L_{c}$ " was determined from the catch curve according to Pauly (1984a \& b).

The relative yield per recruit (Y/R)' and relative biomass per recruit (B/R)' were estimated by using the model of Beverton and Holt (1966) as modified by Pauly and Soriano (1986) and incorporated in the FiSat software package as follows;

$(\mathrm{Y} / \mathrm{R})^{\prime}=\mathrm{E} \mathrm{U} \mathrm{U}^{\mathrm{M} / \mathrm{K}}\left[1-(3 \mathrm{U} / 1+\mathrm{m})+\left(3 \mathrm{U}^{2} / 1+2 \mathrm{~m}\right)-\left(\mathrm{U}^{3} / 1+3 \mathrm{~m}\right)\right]$

$(\mathrm{B} / \mathrm{R})^{\prime}=(\mathrm{Y} / \mathrm{R})^{\prime} / \mathrm{F}$

Where (Y/R)' is the relative yield per recruit,

$(\mathrm{B} / \mathrm{R})^{\prime}$ is the relative biomass per recruit,

$\mathrm{M}$ is the natural mortality coefficient,

$\mathrm{F}$ is the fishing mortality coefficient,

$\mathrm{K}$ is the growth parameter,

$\mathrm{E}$ is the exploitation rate or the fraction of deaths caused by fishing, $\mathrm{m}=(1-\mathrm{E}) /(\mathrm{M} / \mathrm{K})=\mathrm{K} / \mathrm{Z}$, and $\mathrm{U}=1-\left(\mathrm{L}_{\mathrm{c}} / \mathrm{L} \infty\right)$ 


\section{RESULTS AND DISCUSSION}

\section{Lake fishery characteristics}

The total annual catch of Tilapia from Lake Borollus during the period 20002009 (GAFRD, 2009) fluctuated between a minimum catch of 51768 ton in 2000 and a maximum catch of 59785 ton in 2002 with an average of 55207 ton showing a tendency of oscillation with a decreasing trend (Table 1 \& Fig. 1).

Table 1: Total annual fish catch landed from Lake Borollus during 2000 - 2009.

\begin{tabular}{|c|c|}
\hline Year & $\begin{array}{c}\text { Total } \\
\text { Catch(ton) }\end{array}$ \\
\hline 2000 & 51768 \\
2001 & 59200 \\
2002 & 59785 \\
2003 & 55500 \\
2004 & 55000 \\
2005 & 53909 \\
2006 & 52956 \\
2007 & 58291 \\
2008 & 52260 \\
Av. Catch & 53401 \\
\hline
\end{tabular}

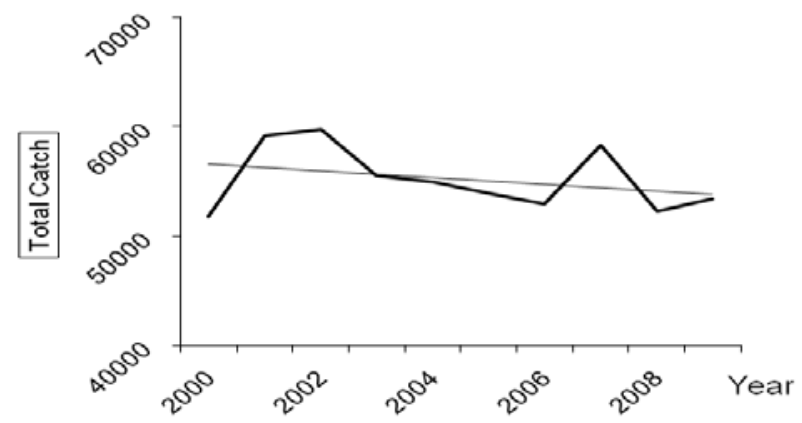

Fig. 1: Total annual fish catch of Lake Borollus during 2000 - 2009.

Tilapia fish formed the majority of fish catch from the lake (38.81\%) followed by catfish (21.74\%) while the mullets represented only $14.44 \%$ in year 2009 . Recently, the decline in the landed catch of tilapia fish was in parallel with an increase of both catfish, mullets and other groups. Hence, the lake total fish catch seems nearly steady with slightly decrease during the last few years, (GAFRD, 2009). Unfortunately, the species constituents of tilapia fish were not identified by GAFRD estimates. It was found that Oreochromis aureus and Oreochromis niloticus dominated the catch of most of the fishing methods in the lake in numerical order, while $O$. niloticus dominated by weight over the others (Al-Sayes, 2005).

\section{Mortality estimates}

Estimation of different mortality parameters were used to characterize the state of various fish populations and as input variables for bio-demographic models like those of Beverton and Holt (1957) and Pet et al. (1996). These models are applied to predict consequences of management measures, like changes in effort and mesh size, on the yield. The estimated vital population parameters of $O$. aureus are summarized in Table (2). 


\section{Mortality Rates}

An estimate of the total mortality coefficient $(\mathrm{Z})$ for $O$. aureus from the descending portion of catch curve (Fig. 2, a-e) was found to be 3.05, 1.83, 1.46, and $1.58 \mathrm{y}^{-1}$ corresponding to Lokaffa net, Trammel net, Basket traps \& Al-Qerba net. The values of $\mathrm{Z}$ for $O$. aureus by these fishing gears are closely similar except that corresponding to the fish caught by lokkafa nets, which may return to the higher effort exerted by such nets leading to over estimation and (or) population and locality differences compared with other gears and (or) zonal variations which may lead to variations in the population of $O$. aureus. The mean value of $\mathrm{Z}\left(1.98 \mathrm{y}^{-1}\right)$ was found less than that recorded by Ishak et al. (1985) $\left(2.626 \mathrm{y}^{-1}\right)$. Also, this value is lower than that estimated by Dowidar et al. (1990) $\left(2.2 \mathrm{y}^{-1}\right)$ for Lake Manzalah. Meanwhile, the natural mortality $(\mathrm{M})$ of $O$. aureus as determined from Pauly's equation (1980) was computed as $1.67,1.01,1.06$, and $1.06 \mathrm{y}^{-1}$ for the respective fishing gears.

Table 2: Estimated vital population parameters for Oreochromis niloticus caught by different fishing gears, at Lake Borollus during (2000-2003).

\begin{tabular}{|l|c|c|c|c|c|c|c|}
\hline Method & $\mathbf{L}_{\infty}$ & $\mathbf{K}$ & $\mathbf{Z}$ & $\mathbf{R}^{2}(\mathbf{Z})$ & $\mathbf{M}$ & $\mathbf{F}$ & $\mathbf{E}$ \\
\hline Lokkafa & 18.28 & 0.87 & 3.05 & 0.9657 & 1.67 & 1.38 & 0.45 \\
Trammel & 19.32 & 0.41 & 1.83 & 0.9660 & 1.01 & 0.82 & 0.45 \\
B. traps & 17.19 & 0.42 & 1.46 & 0.9340 & 1.06 & 0.40 & 0.28 \\
AlQerba & 14.55 & 0.39 & 1.57 & 0.9701 & 1.06 & 0.51 & 0.33 \\
\hline
\end{tabular}

$\mathrm{Z}$ : estimated from length converted catch curve, $\mathrm{F}=\mathrm{Z}-\mathrm{M}, \mathrm{E}=\mathrm{F} / \mathrm{Z}$

$\mathrm{R}^{2}(\mathrm{Z})$ : determination coefficient of $\mathrm{Z}$.

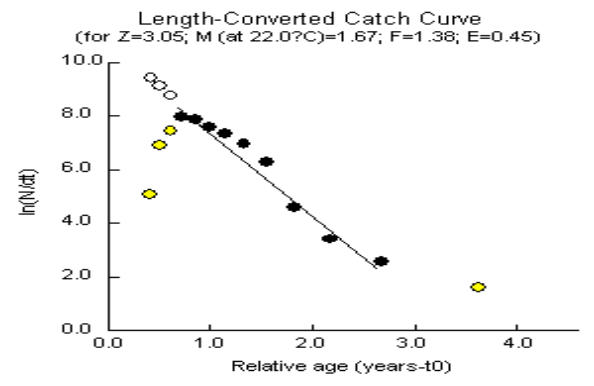

(A) Lokaffa

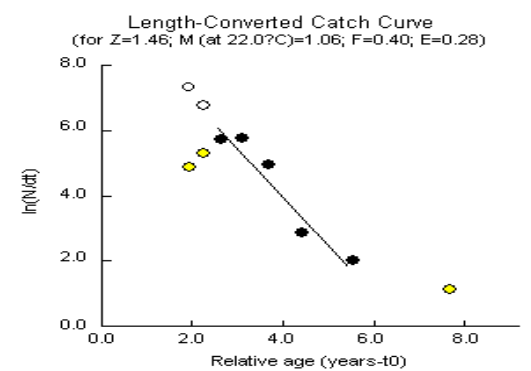

(C) Basket

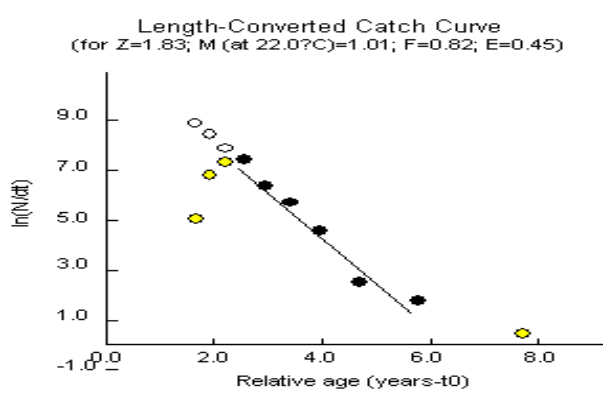

(B) Trammel nets

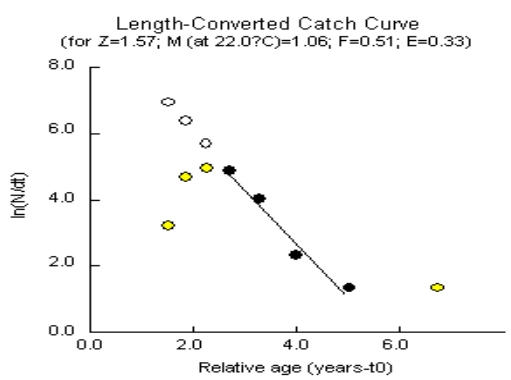

(D) Trawl (Al-qerba) net

Fig. (2 A - D): Length converted catch curves of O. aureus caught by different fishing methods at Lake Borollus during (2002-2003).

The fishing mortality (F) is simply defined as the fraction of the average population taken by fishing. It was computed as $1.38,0.82,0.40$, and $0.51 \mathrm{y}^{-1}$ 
corresponding to the fishing methods in respective order (Table, 2) the differences between these rates could be attributed to the differences between the fishing gears (Dalzell, 1996) as some may catch a wide variety of sizes and species, while others (such as gill and trammel nets) may be very size selective taking only a relatively narrow ranges of lengths depending on the size of the mesh (Acosta. 1994) these findings indicated that $O$. aureus is subjected to moderate fishing mortality rates.

\section{Exploitation Rate}

The exploitation rates (E) of $O$. aureus were determined by using the formula of Gulland (1971) and were found to be $0.45,0.45,0.28$ and 0.33 corresponding to the fore-mentioned fishing gears respectively. According to Gulland (1971), who suggested that in an optimally exploited stock, fishing mortality should be about equal to natural mortality, resulting in a fixed $\mathrm{E}_{\mathrm{opt}}=0.50$. Thus, it was found that the stock of $O$. aureus is under the optimum level $(\mathrm{E}=0.50)$.

\section{Probability of capture and selection ranges}

The length at first capture is strongly correlated with the mesh size of the net used. It was estimated as a component of the length-converted catch curve analysis. $\mathrm{L}_{50}$ values at which $50 \%$ of the fish that become vulnerable to capture were estimated to be $7.64,11.24,10.7$ and $8.34 \mathrm{~cm}$ for $O$. aureus caught by lokaffa net, trammel net, basket traps and Al-Qerba net respectively. Shawky (1999) indicated the sizes of males and females of $O$. quraeus to attain their first maturity were $11.8 \mathrm{~cm}$ and 12.00 $\mathrm{cm}$ respectively. This means that $O$. aureus is caught before being given the chance to grow even to their first size at maturing by most of these fishing methods except those caught by trammel which shows slight higher length which can be returned to the much wider meshes of such nets. (Table 3 \& Fig. 3).

Table 3: Probability of capture and selection ranges of $O$. niloticus caught by different fishing gears at Lake Borollus (2000-2003).

\begin{tabular}{|c|c|c|c|c|}
\hline Fishing & \multirow{2}{*}{$\mathrm{L}_{25}(\mathrm{~cm})$} & $\mathrm{L}_{50}(\mathrm{~cm})$ & $\mathrm{L}_{75}(\mathrm{~cm})$ & $\begin{array}{c}\text { Range } \\
(\mathrm{cm})\end{array}$ \\
\cline { 1 - 4 } Method & 6.86 & 7.64 & 8.48 & 1.62 \\
\hline Lokaffa & 10.45 & 11.24 & 12.11 & 1.66 \\
\hline Trammel & 9.93 & 10.7 & 11.53 & 1.6 \\
\hline B. Traps & 7.57 & 8.34 & 9.23 & 1.66 \\
\hline Al-Qerba & & &
\end{tabular}

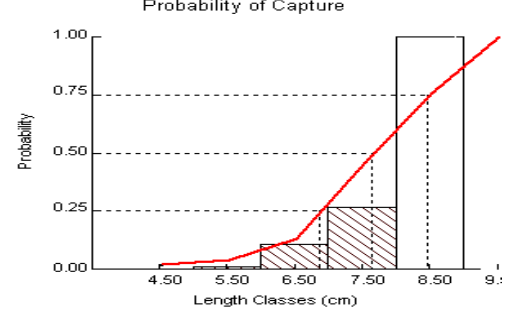

(A) Lokkaffa

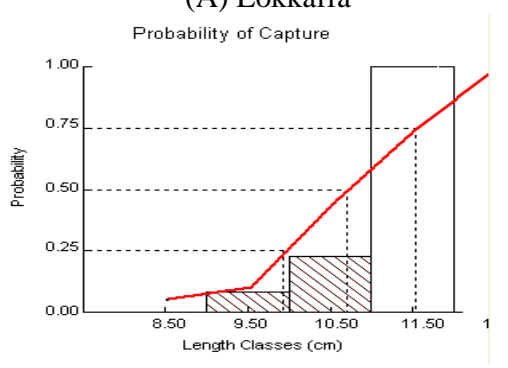

(C) Basket traps

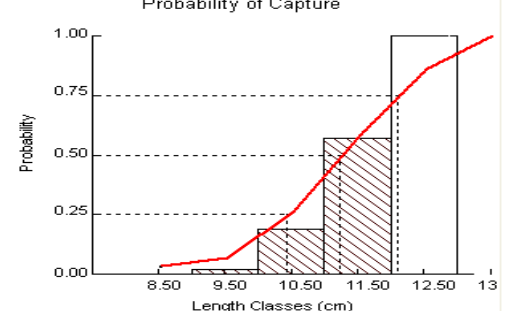

(B) Trammel

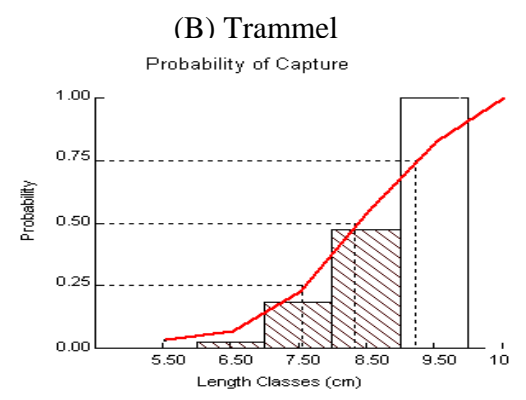

(D) Trawl nets

Fig. (3 A-D): Probability of capture of O. aureus corresponding to different fishing methods at Lake Borollus during (2002-2003). 
The selection range fluctuated between $6.86 \mathrm{~cm}$ and $8.48 \mathrm{~cm}$ total length for $O$. aureus caught by lokkafa nets, while it ranged between $10.45 \mathrm{~cm}$ and $12.11 \mathrm{~cm}$ for that caught by the trammel net. Also, the lower limits of selection ranges were 9.93 and $7.57 \mathrm{~cm}$ for basket traps and Al-Qerba net respectively. While the upper limit didn't exceed $11.53 \mathrm{~cm}$ (in case of basket traps). Consequently, very narrow selection range was observed between these values which were nearly similar. (Table 3).

Relative yield per recruit (Y/R)' and relative biomass per recruit (B/R)

As shown in Figure $(4, a-e)$ for the level of exploitation rate $(0.45)$ was lower than that producing the maximum relative yield per recruit $(0.66)$ by about $20 \%$ for O. aureus caught by Lokaffa method. Similarly the exploitation rates corresponding to the other different fishing methods were lower than that producing the maximum relative yield per recruit.
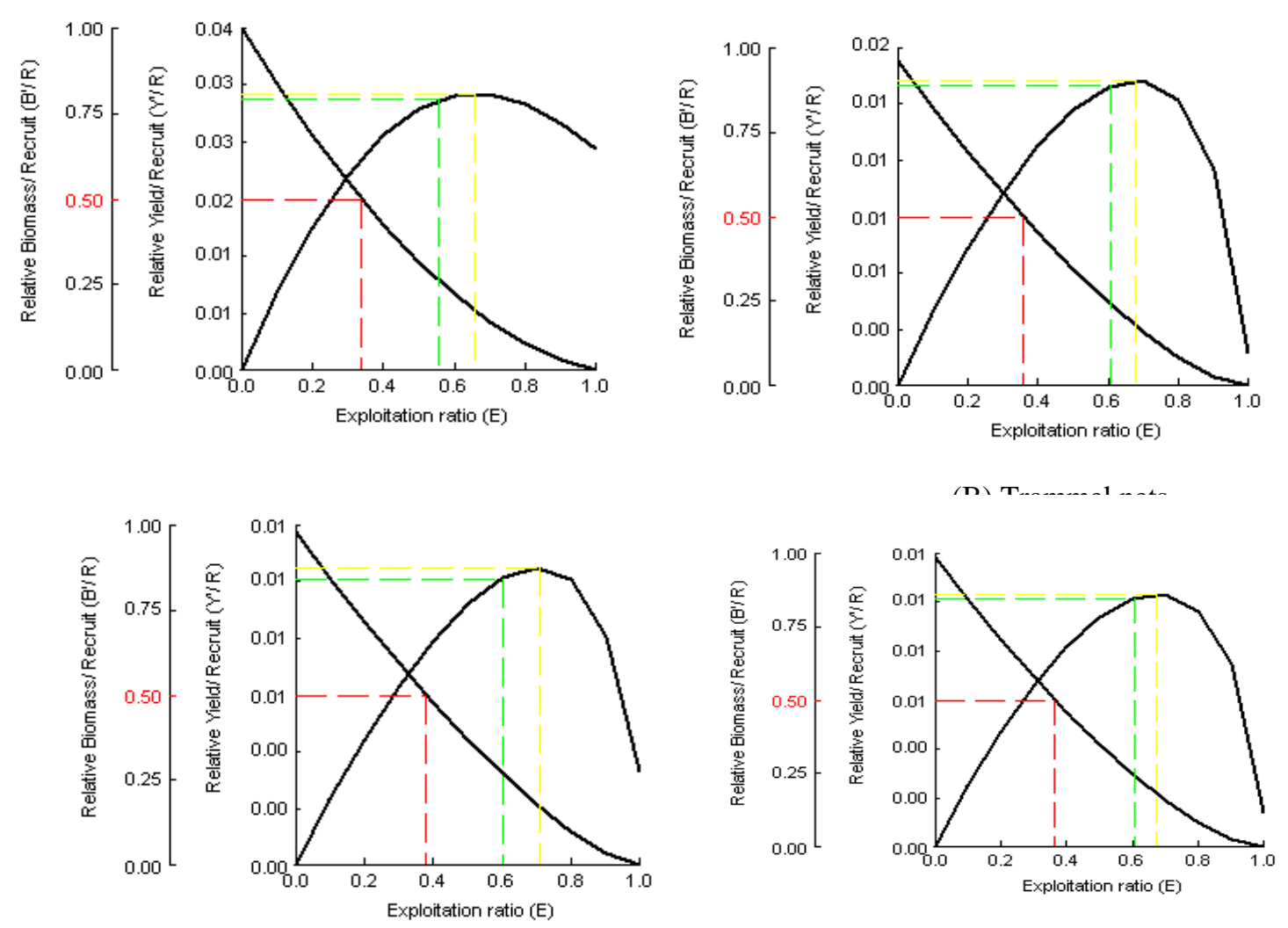

(C) Basket traps

(D) Trawl net

Fig. (4 A-D): Relative yield per recruit (Y/R)' and biomass per recruit (B/R)' of O. aureus, corresponding to different gears at Lake Borollus during (2002-2003)

The exploitation rates $\left(E_{0.1}\right.$, which the increase in relative yield per recruit is one tenth of its value) were found also higher than that estimated from the catch curves. Therefore, additional efforts could be used to reach it and at the same time, larger mesh sized nets should be used in manufacturing the different gears so as to increase the mean catchable lengths and to conserve the reproducible part or the growing part of the population. 


\section{CONCLUSION}

The present results indicated that the stock of $O$. aureus caught by different fishing gears in Lake Borollus could be considered as under exploited. For fishery management of this resource, the fishing pressure should be maintained at the present level of exploitation. The use of illegal mesh sizes and other destructive fishing methods need to be urgently addressed by the authorities concerned as well as raising the mesh sizes of nets used to increase the lower limits of selection ranges corresponding to each fishing gear and also to keep breeding and saving stock biomass of that species.

\section{REFERENCES}

Abd-Alla, A. and Talaat, K. M. (2000). Growth and dynamics of tilapias in Edku Lake, Egypt. Bull. Inst. Ocean. \& Fish. , A.R.E., 26: 183 - 196.

Acosta, A. R. (1994) Soak time and net length effects on catch rate of entangling nets in coral reef areas. Fisheries 19, 105-119.

Al-Sayes, A.A. (1976). Studies on experimental fishing twines and nets and their efficiency and selectivity in fishing operations in Lake Borollus. Ph.D. Thesis, Fac. Sci., Alex. Univ., pp 292.

Al-Sayes, A.A. (2002). Ecological and fisheries management of Edku Lake. 6. Experimental study on the effect of fishing with Seine net on fish populations at Edku Lake. Bull. Nat. Inst. Ocean. Fish : 103-122.

Al-Sayes, A.A. Radwan and L. Shakweer (2007). Impact of drainage water inflow on the environmental conditions and fishery resources of Lak Borollus. Egypt. J. Aquat. Res.: 312-351.

Beverton, R. J. H. and Holt, S. J. (1966). Manual of methods for fish stock assessment. Part 2. Tables of yield functions. FAO Fish. Tech. Pap./FAO Doc.(38) Rev.1:67 p.

Dalzell, P. (1996). Catch rates, selectivity and yields of reef fishing. In: N.V.C. Polunin \& C. M. Roberts (eds) Reef Fisheries. London: Chapman \& Hall, pp. 161-192.

Dowidar, N. M.; Hosny, C. F. H. and Ezzat, A. A. (1990). Mortality and survival rates of Tilapias in Lake Manzalah, Egypt. Proceeding of international symposium on biology and culture of tilapias. 27 - 31 October, Alexandria, Egypt.

El-Bokhty, E. E. B. (2006). Assessment of family Cichlidae inhabiting Lake Manzala, Egypt. Egyptian J. Aquatic Biology and Fisheries, 10: 85-106.

El-Bokhty, E. E. B. (2009). Impacts of Beam Trawl Net (Al-Qerba) on Tilapia Fish Population in Lake Manzalah, Egypt, European J. Biol. Sci. 1 (4): 41-46, 2009.

El-Bokhty, E. E. B. (2010). Fisheries Management of Oreochromis niloticus and Oreochromis aureus Caught by Trammel Nets and Basket Traps in Lake Manzalah, Egypt. World J. of Fish and Marine Sci., 2(1): 51-58.

El-Ganainy, A. A. (2006). The enhancement of the role of women in the artisanal fishing communities to help in improving the livelhood of their families. Women/Youth and the Sea Program 2006 , IOI- project, pp 12.

GAFRD (2009). The General Authority of Fish Resources Development, Year Book of Fishery Statistics, Cairo, Egypt.

Gayanilo, F. C. Jr.; Sparre, P. and Pauly, D. (1997). The FAO-ICLARM Stock Assessment Tools (FiSAT). FAO Computerized Information Series (Fisheries). No. 8 Rome, FAO.

Gulland, J. A. (1971). The fish resources of the Ocean. West Byfleet, Surrey, Fishing News (Books), Ltd., for FAO, 255 p.

Ishak, M. M., A. A. Al-Sayes and K. M. Talaat (1985). Tilapia fisheries in lake Borollus, Egypt. Kuwait Bull. Mar. Sci., 6 (in Arabic with English summary). 
Jackson, J. B. C., Kirby, M. X., Berger, W. H., Bjorndal, K. A., Botsford, L. W., Bourque, B. J., Bradbury, R. H., Cooke, R., Erlandson, J., Estes, J. A., Hughes, T. P., Kidwell, S., Lange, C. B., Lenihan, H. S., Pandolfi, J. M., Peterson, C. H., Steneck, R. S., Tegner, M. J., and Warner, R. R. (2001). Historical overfishing and the recent collapse of coastal ecosystems. Science, 293: 629-638.

Khalifa, U. S. A., Agaypi, M. Z. and Adam, H. A. (2000). Population dynamics of Oreochromis niloticus L. and Sarotherodon galilaeus Art. 90-97. In: Sustainable Fish Production in Lake Nasser: Ecological Basis and Management Policy. J. F. Craig (ed.) ICLARM Con. Proc., 61:184 p.

Khallaf, E. A.; Galal, M. and Authman, M. (2000). The biology of Oreochromis niloticus in a polluted canal. In the International Congress on the Biology of Fish. 20-23 July 2000, University of Aberdeen, Scotland, UK. Pp: 17.

Khallaf, E. A. (2002). An ecological assessment of Bahr Shebeen Nilotic Canal (A Review Paper, presented at the 9th International Conference, 1-6 September, 2002, Aleppo University, Syria). J. Union Arab Biol. Vol 17 (A): 65-75.

Pauly, D. (1983). Some simple methods for assessment of tropical fish stocks. FAO Fish. Tech. Pap., 234-252 p.

Pauly, D. (1984a). Length-converted catch curves. A powerful tool for fisheries research in the tropics. Part 1. ICLARM Fishbyte, 1 (2): 9-13 .

Pauly, D. (1984b). Recent developments in the methodology available for the assessment of exploited fish stocks of reservoirs. In Status of African reservoir fisheries. CIFA Tech. Pap. (10): 326 pp. Ed. By Kapatasky, J. M. and T. Petr.

Pauly, D. and Soriano, M. L. (1986). Some practical extensions to Beverton and Holt's relative yield- per- recruit model. In: J. L. Maclean, L. B. Dizon and L. V. Hosillo (eds., The first Asian Fisheries Forum. 491-496).

Pet, J.S.; Machiels, M.A.M. and van Densen, W.L.T. (1996). A size structured model for evaluating management strategies in gillnet fisheries exploiting spatially differentiated populations. Ecological Modelling 88: 195-214.

Shawky, K.A.(1999). Factors affecting the efficiency and selectivity of trammel nets at Manzalah lake. Ph. D. Thesis. Fac. Sci. Zagazig Univ.

Wetherall, J.A. (1986). A new method for estimating growth and mortality parameters from length-frequency data. ICLARM Fishbyte, 4(1): 12-14.

\section{ARABIC SUMMARY}

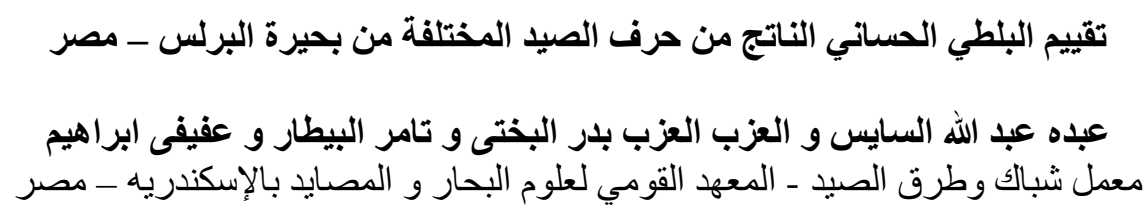

تم تقييم البلطي الحساني الناتج باستخدام حرف الصيد المختلفة في بحيرة البرلس عن طريق استخدام

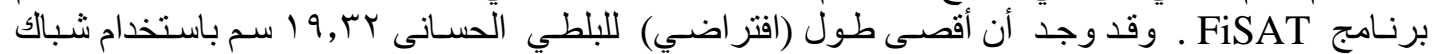

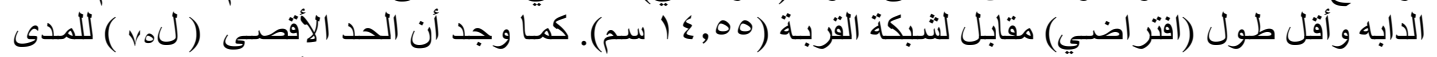

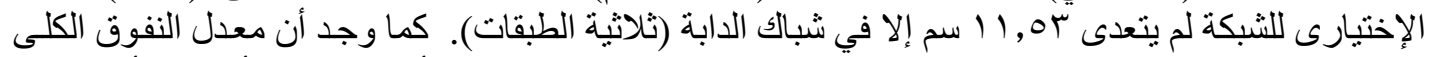

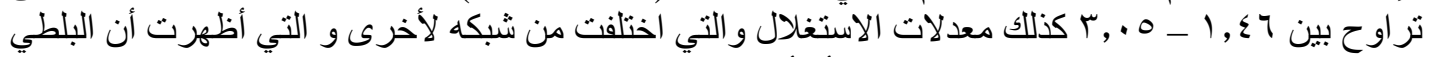

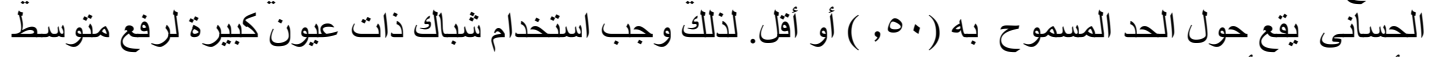

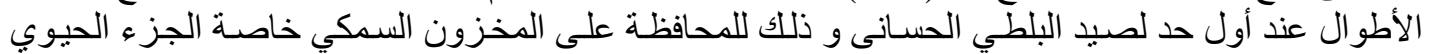

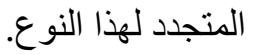

